\title{
Management Information Systems in Public Institutions in Jordan
}

\author{
An Eye on Implementation Success Factors and their Relationship with Organizational \\ Performance
}

\author{
Ahmad A. Al-Tit \\ Department of Business Administration \\ Qassim University \\ Buraidah, KSA
}

\begin{abstract}
Six constructs were utilized in this study to explore the factors affecting MIS implementation in Jordanian public institutions and to investigate the impact of MIS implementation on organizational (operational) performance. They were human factors, organizational factors, technological factors, environmental factors, MIS implementation components and organizational performance. The required data were collected using a valid and reliable questionnaire developed based on the literature review. Human factors were conceptualized as users' computer skills and experience, IS usefulness and IS ease of use. Organizational factors were assessed using three sub-indicators, which were top-management support, user training and IS confidentiality. Technological factors were evaluated by systematic quality, information quality and service quality. The overall industry, industry environment and external pressure were three indicators used to measure the environmental factors. Two variables were selected to measure MIS implementation: IT/IS capability and technological aspects related to information service quality. Since the current study tackled public institutions, the indicators of organizational performance were limited to operational ones. The questionnaire was distributed to 125 informants from IT/IS departments. The findings of the study indicated the acceptance of the hypothesis that the factors in question are significantly and positively related to MIS implementation, which in turn, when measured by IT/IS capability and information service quality, significantly and positively affect organizational performance. The main contribution provided by this study is that MIS implementation is not limited to information technology and systems capabilities and usefulness. Other factors should be considered, particularly when examining the impact of MIS implementation on organizational performance.
\end{abstract}

Keywords-management information systems; adoption success factors; organizational performance; public institutions

\section{INTRODUCTION}

Researchers have propounded a number of reasons behind the importance of management information systems (MISs). Lipaj and Davidavičiene [1] and Kharuddin et al [2] indicated that one of these reasons is related to the role that MISs play in business performance enhancement. Although many organizations have adopted MISs, not all of them have achieved the presumed benefits [3]. Hence, considerable attention has been paid to the factors that play a critical role in the successful implementation of MIS. Two lines of research have been merged. The first one focuses on the factors affecting the implementation of MISs in different industries, while the other addresses the relationship between MISs and organizational performance.

On the one side, Al-Mamary et al [4] performed a study to explore the factors affecting the successful implementation of MISs in Yemeni organizations. They categorized these factors into technological factors, people factors and organizational factors. In 2015 Al-Mamary et al [5] found a positive relationship between these factors and organizational performance (OP). Using a sample consisting of 100 French organizations, Bacha [6] highlighted the significance of topmanagement and employee attitudes in the implementation of MISs. In Kuwait Alshawaf and Khalil [7] identified four success factors of information systems (ISs): information systems' strategy and resources, end-user support, information systems' sophistication and information systems' organizational level and user involvement.

In the United States, Kearns [8] studied the relationship between two major factors' impacts on IS planning and implementation, namely top-management support of ISs and management participation in IS planning. The results indicated that these two variables significantly reduced IS implementation problems. Farzandipur et al [3] sorted the factors affecting the implementation of MISs in hospitals into human factors (computer skills, IS usefulness and IS ease of use), managerial and organizational factors (IS project management, IS cost, training, user participation and IS confidentiality) and technological factors (support, safety, development and communication). Rahimi et al [9] brought user participation in the development stages of IS to light as a critical factor that affects the development of ISs in hospitals. According to them, users can take part in four stages of IS development: analysis, design, implementation and evaluation.

Fu et al [10] listed three main factors that influence the adoption of ISs by small and medium-sized enterprises in Taiwan. Those factors are technological factors, organizational factors and environmental factors. Each group of them relates to three types of objectives. Specifically, technological factors are related to the system function, technology trust and cognition benefit; organizational factors are interconnected to organizational characteristics, the organization's readiness and the partners' willingness and 
abilities; and, finally, environmental factors are linked to the overall industry, industry environment and external pressure. Detailed criteria levels for these factors can be seen in Table 1. However, the authors deemed six out of these factors to be critical success factors.

On the other side, Al-Gharaibeh and Malkawi [11] carried out a case study of the Ministry of Planning to investigate the relationship between MISs and OP. Three dimensions of MISs were used: hardware and software components, networks, and individuals and procedures. According to their results, MISs have an impact on organizational performance in Jordanian public settings. Analysing data collected from thirteen countries, DA Silveira and Cagliano [12] explored and confirmed the relationship between inter-organizational information systems (computerized networks used for information exchange) and operational performance. Batra [13] hypothesized an impact of information technology (IT) on organizational effectiveness. The findings pointed out that IT has an impact on the overall organizational flexibility, which in turn influences the organizational performance of organizations and hence their organizational effectiveness.

Building on the above-mentioned literature, the purpose of this study is twofold: first, to explore the factors affecting the implementation of MISs in Jordanian governmental institutions; and second, to explore the relationship between MIS components and organizational performance in those institutions.

\section{LITERATURE REVIEW AND HYPOTHESIS DEVELOPMENT}

\section{A. MIS Definition, Requirements and Dimensions}

Management information systems (MISs) are one of the five types of information systems. The other four types are office information systems (OISs), transaction-processing systems (TPSs), decision support systems (DSSs) and executive support systems (ESS) [1]. MISs have been defined by researchers in terms of their ability to provide information with good characteristics on which organizations depend to enhance their performance [5]. Other definitions have tackled MISs with regard to their functions, such as collecting, recording, storing and rearranging data [14]. Given that the first major aim of this study is to identify the factors affecting MIS implementation in Jordanian governmental institutions, a literature review was conducted. Examples of those factors are presented in Table 1.

TABLE I. FACTORS THAT AFFECT MIS ADOPTION AS DEPICTED IN THE LITERATURE

\begin{tabular}{|ll|l|}
\hline MIS requirements & Reference (s) \\
\hline- & Technological factors: & \\
- & System quality & \\
- & Information quality & \\
- & Service quality & Al-Mamary et al. \\
- & Organizational factors: & not defined.] \\
- & Top management support & \\
- & User training & \\
$\bullet$ & People factors: & \\
- & Computer self-efficacy & Alshawaf and \\
- & User experience. & Khalil [Error! \\
\hline$\bullet$ & Information systems strategy and resources. \\
$\bullet$ & End user support. & \\
\hline
\end{tabular}

\begin{tabular}{|c|c|c|}
\hline & $\begin{array}{l}\text { Information systems sophistication. } \\
\text { IS organizational level and user involvement. }\end{array}$ & $\begin{array}{l}\text { Bookmark not } \\
\text { defined.] }\end{array}$ \\
\hline - & $\begin{array}{l}\text { Internal environment factors } \\
\text { Top-management support } \\
\text { Managers' participation in IS planning }\end{array}$ & $\begin{array}{l}\text { Kearns [Error! } \\
\text { Bookmark not } \\
\text { defined.] }\end{array}$ \\
\hline & $\begin{array}{l}\text { User participation in IS development: } \\
\text { Analysis. } \\
\text { Design. } \\
\text { Implementation. } \\
\text { Evaluation. }\end{array}$ & $\begin{array}{l}\text { Rahimi et at. } \\
\text { [Error! Bookmark } \\
\text { not defined.] }\end{array}$ \\
\hline & $\begin{array}{l}\text { Human factors: } \\
\text { Computer skills. } \\
\text { IS usefulness. } \\
\text { IS ease to use. } \\
\text { Managerial and organizational factors: } \\
\text { IS project management. } \\
\text { IS cost. } \\
\text { Training. } \\
\text { User participation. } \\
\text { IS confidentiality. } \\
\text { Technological factors: } \\
\text { Support. } \\
\text { Safety. } \\
\text { Development. } \\
\text { Communication. }\end{array}$ & $\begin{array}{l}\text { Farzandipur, et al. } \\
\text { [Error! Bookmark } \\
\text { not defined.] }\end{array}$ \\
\hline & $\begin{array}{l}\text { Technological factors: } \\
\text { System function, technology trust, and cognition } \\
\text { benefits. } \\
\text { Organizational factors: organization } \\
\text { characteristics and readiness, and partners' } \\
\text { willingness and abilities. } \\
\text { Environmental factors: overall industry, industry } \\
\text { environment, and external pressure. }\end{array}$ & $\begin{array}{l}\text { Fu et al. [Error! } \\
\text { Bookmark not } \\
\text { defined.] }\end{array}$ \\
\hline
\end{tabular}

Consequently, the current study categorized the factors that have an influence on the adoption of ISs in organizations into four groups: human factors, organizational factors, technological factors and environmental factors. Regarding MIS components, Zhu and Nakata [15] argued that the most important components of MISs are IT capability and information service quality. Benitez-Amado and Walczuch [16] conceptualized IT capability in their study as a dependent variable that represents an organization's ability to use IT resources. Table 2 shows the major components of MISs in the literature. The current study focuses on IT capability and information service quality in addition to hardware and software components.

TABLE II. MAJOR COMPONENTS OF MISS FOUND IN THE LITERATURE

\begin{tabular}{|c|c|}
\hline MIS components & Reference (s) \\
\hline $\begin{array}{ll}- & \text { IT capability: } \\
- & \text { Information storage. } \\
- & \text { Information processing } \\
- & \text { Information communication } \\
\text { - } & \text { Information services quality: } \\
- & \text { Service timeliness. } \\
- & \text { Service appropriateness } \\
- & \text { Information reliability. }\end{array}$ & Zhu and Nakata [15] \\
\hline $\begin{array}{l}\text { IT capability: organizations } \\
\text { ability to use IT resources }\end{array}$ & Benitez-Amado and Walczuch [16] \\
\hline $\begin{array}{ll}\text { - } & \text { Hardware and software } \\
\text { components } \\
\text { - } & \text { Networks } \\
\text { - } & \text { Individuals and procedures }\end{array}$ & AL-Gharaibeh and Malkawi [11] \\
\hline $\begin{array}{ll}\text { - } & \text { Timeliness } \\
\text { - } & \text { Scope } \\
\text { - } & \text { Aggregation }\end{array}$ & Naranjo-Gil [17] \\
\hline
\end{tabular}


- Integration

\section{B. Organizational Performance}

According to Al-Tit and Hunitie [18], OP can be defined as a measure employed to identify organizations' efficiency and effectiveness in achieving their goals. In general, two types of measures were used to evaluate organizational performance: financial and non-financial measures [19]. Table 3 presents the different indicators used in the literature to measure OP. Given that this study was conducted on public institutions, OP was measured in terms of operational dimensions, that is, nonfinancial measurements.

TABLE III. OP DIMENSIONS DEPICTED IN THE LITERATURE

\begin{tabular}{|c|c|}
\hline OP dimensions & Reference (s) \\
\hline $\begin{array}{ll}- & \text { Internal process performance: } \\
- & \text { Internal process simplification. } \\
- & \text { Data validity improvement. } \\
- & \text { Internal communication } \\
& \text { efficiency. } \\
- & \text { Financial performance: } \\
- & \text { Sales increase. } \\
- & \text { Inventory turnover reduction. } \\
- & \text { Receivable turnover increase. } \\
- & \text { Profit margin growth. }\end{array}$ & Lipaj and Davidavičienè [1] \\
\hline $\begin{array}{ll}- & \text { Financial measures: } \\
- & \text { Cost of funds } \\
- & \text { Non-interest income } \\
- & \text { Earnings per share } \\
- & \text { Capital structure } \\
- & \text { Return on investment } \\
\text { - } & \text { Loan yield } \\
\text { - } & \text { Market ratios } \\
- & \text { Liquidity } \\
\text { - } & \text { Cash flow from operations } \\
\text { Relative market share and } \\
\text { position } \\
\text { Operating income } \\
\text { - } \\
\text { Revenues } \\
\text { - Customers' profitability } \\
\text { Non-financial measures: } \\
\text { - } \quad \text { Customer-employee-based } \\
\text { performance: Responsiveness, } \\
\text { personnel development, no. of } \\
\text { customer's complaints, } \\
\text { accessibility, delivery speed } \\
\text { flexibility, customer } \\
\text { satisfaction, on-time service, } \\
\text { employee skills, } \\
\text { communication, competence, } \\
\text { productivity, efficiency, } \\
\text { availability, courtesy and } \\
\text { quality. } \\
\text { Innovation-based performance: } \\
\text { Performance of individual } \\
\text { innovations, performance of the } \\
\text { innovation process, research and } \\
\text { development, new product } \\
\text { development, volume } \\
\text { flexibility, and specification } \\
\text { flexibility. }\end{array}$ & Salleh et al. [20] \\
\hline $\begin{array}{ll} & \text { Work efficiency } \\
\text { - } & \text { Work effectiveness } \\
\text { - } & \text { Decision making } \\
\end{array}$ & Alshawaf and Khalil [7] \\
\hline - $\quad$ Sectoral excellence & Benitez-Amado and Walczuch [16] \\
\hline - $\quad$ Satisfaction of employees & $\begin{array}{l}\text { Gil-Padilla and Espino-Rodríguez } \\
\text { [19] }\end{array}$ \\
\hline
\end{tabular}

\section{Factors Affecting the Adoption of MISs}

Fu et al [10], Al-Mamary et al [5] and Farzandipur et al [3] suggested four groups of factors that have an influence on the adoption of MISs: human factors, organizational factors, technological factors and environmental factors. Following these recent studies, the current study applied the same factors. Therefore, the following hypotheses were posed:

H01: Human factors significantly advance MIS implementation.

H02: Organizational factors significantly elevate MIS implementation.

H03: Technological factors significantly support MIS implementation.

H04: Environmental factors significantly improve MIS implementation.

\section{Relationship between MISs and OP}

Al-Mamary et al [5] carried out a study on the relationship between the success factors of MISs and the organizational performance in the telecommunication industry in Yemen. Their hypotheses were supported. That is, technological (system quality, information quality and service quality), organizational (top-management support and user training) and people factors (computer self-efficacy and user experience) were positively related to organizational performance. In their work on information systems' success factors and the organizational performance of public and private organizations, Alshawaf and Khalil [7] found significant differences between public and private organizations with regard to end-user support, top management and information systems management in IS financial decisions in favour of public organizations. They also found significant differences in terms of IS resource availability, top-management involvement in the IS strategy, end-user involvement in IS development and end-user training on information technology in favour of private organizations. The study revealed no significant differences between private and public organizations in Kuwait with respect to the age of IS units, IS organizational levels, IS sophistication or the perceived obviousness of the IS strategy. Ravichandran and Lertwomgsatien [21] found a positive relationship between IS human capital (IS skills and specificity), IT infrastructure flexibility (networks' and applications' sophistication), IS partnership quality (internal and external partnership quality) and organizational performance (operating and market-based performance) of different organizations from numerous industries such as banking, insurance, financial services, retail, manufacturing and services, transportation and utilities in the United States. As a result, the following hypothesis was postulated:

\section{H05: MIS implementation has a positive impact on organizational performance.}

\section{Study Measurement Model}

Figure 1 displays the measurement model of the study, in which four constructs (human factors, organizational factors, technological factors and environmental factors) were 
assumed to have an impact on OP. Hypotheses 1-4 postulated significant relationships between those factors and MIS implementation in Jordanian public institutions. Hypothesis 5 presumed that MIS adoption has a significant impact on the overall OP of public institutions as measured by internal process performance, customer satisfaction, employee satisfaction and work efficiency and effectiveness.

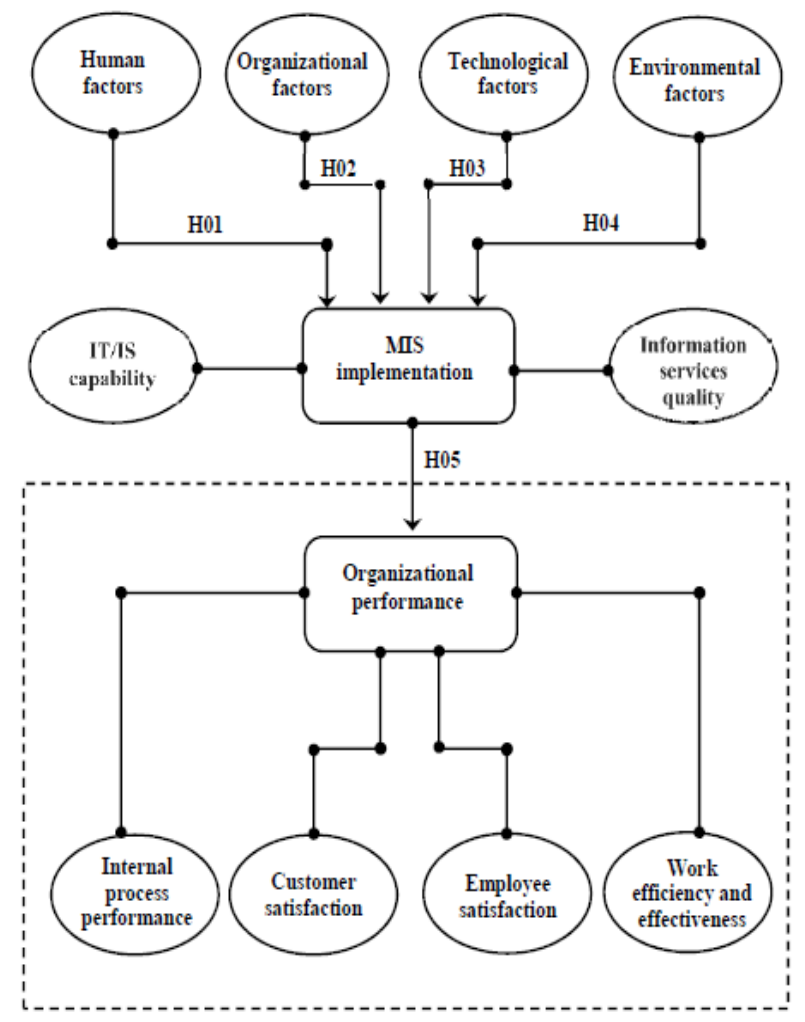

Fig. 1. Study measurement model

\section{METHODOLOGY}

\section{A. Sample and Data Collection}

The current study was conducted in Jordanian public institutions. A sample consisting of 25 governmental institutions in Amman was selected to collect the required data. The analysis unit used comprises managers as well as employees working in IT/IS departments. A 5-point questionnaire was developed based on related work on IS implementation and organizational performance. It was anchored at "strongly disagree" for responses of 1 and "strongly agree" for responses of 5. A total of 125 questionnaires were distributed to the participants, out of which 73 were returned, which means a 58 per cent response rate. This rate is judged to be high, since the responses are limited to IT/IS departments.

\section{B. Measures}

The factors that might affect MIS implementation in public institutions were measured by the human factors, organizational factors, technological factors and environmental factors adapted from Fu et al [10], Al-Mamary et al [5] and Farzandipur et al [3]. Seven items based on Zhu and Nakata [15] and Al-Gharaibeh and Malkawi [11] were used to measure MIS implementation (IT/IS capability and information service quality). Organizational performance was measured using eight items concerning internal process performance, customer satisfaction, employee satisfaction, work efficiency and effectiveness. The dimensions used to measure OP were adapted from Lipaj and Davidavičienė [1], Salleh et al [20], Alshawaf and Khalil [7] and Gil-Padilla and Espino-Rodríguez [19]. Table 4 shows the study constructs, codes, indicators and number of items.

TABLE IV. STUdy CONSTRUCTS, CODES, INDICATORS AND NUMBER OF ITEMS

\begin{tabular}{|ll|c|l|l|}
\hline Constructs & Code & Indicators & $\begin{array}{l}\text { No. of } \\
\text { items }\end{array}$ \\
\hline$\bullet$ & MIS Factors & MISF & & $\mathbf{1 2}$ \\
\hline- & Human factors & HUF & HUF1 - HUF3 & 3 \\
\hline- & Organizational factors & ORF & ORF1 - ORF3 & 3 \\
\hline- & Technological factors & TEF & TEF1 - TEF3 & 3 \\
\hline- & Environmental factors & ENF & ENF1 - ENF3 & 3 \\
\hline$\bullet$ & MIS implementation & MISI & & $\mathbf{7}$ \\
\hline- & IT/IS capability & ISC & ISC1 - ISC4 & 4 \\
\hline- & Information service quality & ISQ & ISQ1 - ISQ3 & 3 \\
\hline$\bullet$ & $\begin{array}{l}\text { Organizational } \\
\text { performance }\end{array}$ & ORP & & $\mathbf{8}$ \\
\hline- & Internal process performance & IPP & IPP1 \& IPP2 & 2 \\
\hline- & Customer satisfaction & CST & CST1 \& CST2 & 2 \\
\hline- & Employee satisfaction & EMS & EMS1 \& EMS2 & 2 \\
\hline- & $\begin{array}{l}\text { Work efficiency and } \\
\text { effectiveness. }\end{array}$ & WEE & WEE1 \& WEE2 & 2 \\
\hline
\end{tabular}

\section{Validity and Reliability}

Two types of validity are tested in this section: content validity and convergent validity. Five academic experts evaluated the content validity. The convergent validity was assessed using the average variance extracted (AVE). On the other hand, two coefficients were used to rate reliability: Cronbach's alpha coefficients and composite reliability coefficients. The results of the validity and reliability tests summarized in Table 5 indicate that the scale used in this study is valid and reliable, as all the values of AVE are greater than 0.6 [ ], all the Cronbach's alpha coefficients are above 0.7 [8] and all the coefficients of composite reliability are above 0.6[] .

TABLE V. RESULTS OF VALIDITY AND RELIABILITY TESTS

\begin{tabular}{|l|l|l|l|}
\hline Variable & AVE & $\begin{array}{l}\text { Cronbach's } \\
\text { alpha }\end{array}$ & $\begin{array}{l}\text { Composite } \\
\text { reliability }\end{array}$ \\
\hline Human factors & 0.64 & 0.73 & 0.65 \\
\hline Organizational factors & 0.66 & 0.81 & 0.77 \\
\hline Technological factors & 0.73 & 0.87 & 0.73 \\
\hline Environmental factors & 0.69 & 0.76 & 0.80 \\
\hline MIS implementation & 0.71 & 0.89 & 0.69 \\
\hline $\begin{array}{l}\text { Organizational } \\
\text { performance }\end{array}$ & 0.74 & 0.88 & 0.82 \\
\hline
\end{tabular}

\section{Pearson's Product-Moment Correlation Coefficient}

The Pearson's matrix shown in Table 6 illustrates the significant relationships between the factors affecting MIS implementation and MIS implementation as measured by IT/IS capability (ISC) and information service quality (ISQ). It appears that human factors (HUFs) are significantly correlated with both dimensions of MIS implementation ( $\mathrm{r}=$ 0.57 and $\mathrm{r}=0.61, \mathrm{p}<0.05)$. Additionally, organizational 
factors (ORFs) are significantly correlated with both dimensions of MIS implementation $(\mathrm{r}=0.50$ and $\mathrm{r}=0.55, \mathrm{p}<$ $0.05)$, along with technological factors $(r=0.61$ and $r=0.43$, $\mathrm{p}<$ 0.05). Finally, environmental factors (ENFs) are significantly correlated with ISC $(r=0.39, \mathrm{p}<0.05)$ and ISQ $(\mathrm{r}=0.31)$. The results also revealed a significant correlation between the two dimensions of MIS implementation.

TABLE VI. CORRELATIONS BETWEEN MIS FACTORS AND MIS IMPLEMENTATION

\begin{tabular}{|l|l|l|l|l|l|l|}
\hline & HUF & ORF & TEF & ENF & ISC & ISQ \\
\hline HUF & - & & & & & \\
\hline ORF & 0.44 & - & & & & \\
\hline TEF & 0.51 & 0.48 & - & & & \\
\hline ENF & 0.46 & 0.37 & 0.45 & - & & \\
\hline ISC & 0.57 & 0.50 & 0.61 & 0.39 & - & \\
\hline ISQ & 0.61 & 0.55 & 0.43 & 0.31 & 0.47 & - \\
\hline
\end{tabular}

\section{DATA ANALYsis}

\section{A. Descriptive Statistics of the Factors Affecting MIS Implementation}

Frequencies, percentages, mean scores and standard deviations were extracted, as shown in Table 7, to identify the frequencies and percentages of the responses to the scale points. The results obtained were used to categorize the factors affecting MIS implementation according to their importance.

TABLE VII. MEAN SCORES OF THE FACTORS AFFECTING MIS IMPLEMENTATION

\begin{tabular}{|ll|l|l|l|l|l|l|l|l|}
\hline MISF & $\mathbf{N}(\boldsymbol{\%})$ & $\mathbf{5}$ & $\mathbf{4}$ & $\mathbf{3}$ & $\mathbf{2}$ & $\mathbf{1}$ & Mean & SD \\
\hline$\bullet$ & HUF & $\mathbf{7 3 ( 1 0 0 )}$ & - & - & - & - & - & $\mathbf{4 . 0 4}$ & $\mathbf{1 . 0 7 0}$ \\
\hline- & HUF1 & & $33(45)$ & $17(23)$ & $11(15)$ & $7(.09)$ & $5(.07)$ & 4.15 & 0.877 \\
\hline- & HUF2 & & $29(40)$ & $16(22)$ & $9(12)$ & $11(15)$ & $8(0.1)$ & 3.99 & 0.965 \\
\hline- & HUF3 & & $27(39)$ & $18(25)$ & $12(16)$ & $9(12)$ & $7(.09)$ & 3.97 & 1.000 \\
\hline$\bullet$ & ORF & $\mathbf{7 2 ( 9 9 )}$ & - & - & - & - & - & $\mathbf{3 . 9 2}$ & $\mathbf{0 . 6 8 2}$ \\
\hline- & ORF1 & & $24(33)$ & $11(15)$ & $28(39)$ & $4(.06)$ & $5(.07)$ & 3.94 & 0.714 \\
\hline- & ORF2 & & $30(42)$ & $18(25)$ & $17(24)$ & $6(.08)$ & $1(.01)$ & 3.92 & 1.100 \\
\hline- & ORF3 & & $22(31)$ & $17(24)$ & $10(14)$ & $13(18)$ & $10(14)$ & 3.90 & 0.594 \\
\hline - & TEF & $\mathbf{7 1 ( 9 7 )}$ & - & - & - & - & - & $\mathbf{3 . 7 2}$ & $\mathbf{0 . 4 1 6}$ \\
\hline- & TEF1 & & $20(27)$ & $21(29)$ & $13(18)$ & $12(16)$ & $7(.09)$ & 3.89 & 0.947 \\
\hline- & TEF2 & & $19(26)$ & $24(33)$ & $11(15)$ & $7(.09)$ & $12(16)$ & 3.85 & 0.721 \\
\hline- & TEF3 & & $15(21)$ & $19(26)$ & $20(27)$ & $12(16)$ & $7(.09)$ & 3.77 & 0.605 \\
\hline$\bullet$ & ENF & $\mathbf{7 3 ( 1 0 0 )}$ & - & - & - & - & - & $\mathbf{3 . 2 7}$ & $\mathbf{0 . 8 1 9}$ \\
\hline- & ENF1 & & $11(15)$ & $16(22)$ & $20(27)$ & $18(25)$ & $8(0.1)$ & 3.67 & 0.700 \\
\hline- & ENF2 & & $15(21)$ & $37(51)$ & $2(.03)$ & $9(12)$ & $10(14)$ & 3.66 & 0.601 \\
\hline- & ENF3 & & $25(34)$ & $14(19)$ & $16(22)$ & $7(.09)$ & $11(15)$ & 3.37 & 0.814 \\
\hline
\end{tabular}

It was concluded, based on the results in Table 7, that human factors are the most important factors in MIS implementation $(\mathrm{M}=4.04, \mathrm{SD}=1.070)$, followed by organizational factors $(\mathrm{M}=3.92, \mathrm{SD}=0.682)$, then technological factors $(\mathrm{M}=3.72, \mathrm{SD}=0.416)$ and finally environmental factors $(\mathrm{M}=3.27, \mathrm{SD}=0.819)$.

\section{B. Structural Model}

The results of the confirmatory factor analysis (CFA) established the goodness of fit of the data: the comparative fit index $(\mathrm{CFI})=0.931$, the normalized chi-square $(\chi 2 / \mathrm{df})=1.66$, the goodness of fit index $(\mathrm{GFI})=0.913$ and the root mean square error of approximation (RMSEA) $=0.051$. Consequently, the overall fit was supported, as illustrated in Figure 2. Grounded on the path coefficients of the structural model, the associations between human factors (H01), organizational factors (H02), technological factors (H03) and environmental factors (H04) and MIS implementation are significant and positive. In other words, the model supported all the concerning factors affecting MIS implantation. Still, for hypothesis 5 a significant impact of MIS implementation, measured by IT/IS capability and information service quality, on the organizational performance was found.

\section{Multiple Regression Analysis}

Hypothesis 5 supposed that MIS implementation has a significant impact on organizational performance. Multiple regression analysis was conducted to test this hypothesis. The independent variable was MIS implementation and the independent variable was organizational performance. The regression findings displayed in Table 8 indicate that the MIS implementation dimensions have a positive and significant impact on the organizational performance of public institutions. MIS implementation explained $40 \%$ of the variance in the organizational performance. The $\mathrm{F}$ (33.16), $\beta$ (0.514), t (5.106) and $\mathrm{P}$ values (0.000) verify this result.

TABLE VIII. REGRESSION RESULTS FOR MIS IMPLEMENTATION AND ORGANIZATIONAL PERFORMANCE

\begin{tabular}{|l|l|l|l|l|l|l|}
\hline \multicolumn{2}{|l|}{ Model summary } & \multicolumn{4}{l|}{ ANOVA } & \multicolumn{3}{l|}{ Coefficients } \\
\hline $\mathrm{r}$ & $\mathrm{R}^{2}$ & $\mathrm{~F}$ & $\mathrm{P}$ & $\beta$ & $\mathrm{t}$ & $\mathrm{P}$ \\
\hline 0.631 & 0.40 & 33.16 & 0.000 & 0.514 & 5.106 & 0.000 \\
\hline
\end{tabular}

\section{Final Model}

Founded on the previously mentioned results, the final model of the study shown in Figure 2 demonstrates a positive correlation between human factors $(\mathrm{r}=0.59)$, organizational factors $(r=0.53)$, technological factors $(r=0.52)$ and environmental factors $(r=0.35)$. Human factors ranked first as the most correlated factors in MIS implementation from the respondents' perspective $(\mathrm{M}=4.04)$, followed by organizational factors $(\mathrm{M}=3.92)$, then technological factors $(\mathrm{M}=3.72)$ and environmental factors $(\mathrm{M}=3.27)$. The significant and positive impact of MIS implementation on organizational performance was supported using the current data $(\beta=0.514, \mathrm{t}=5.106, \mathrm{P}=0.000)$.

\section{DISCUSSION AND CONCLUSION}

The aim of this study was to explore the factors affecting MIS implementation in Jordanian public institutions. Four major factors were identified based on the literature: human factors, organizational factors, technological factors and environmental factors. On the other hand, the study aimed to investigate the impact of MIS implementation on organizational performance.

The results revealed that human factors, organizational factors, technological factors and environmental factors are significantly related to MIS implementation. That is, users' skills and experience, IS usefulness, IS ease of use, topmanagement support, user training, IS confidentiality, system quality, information quality, service quality, overall environment, institutional environment and external pressure are all factors that contribute to the success of MIS implementation. In line with these findings, Al-Mamary et al [4], Bacha [6], Alshawaf and Khalil [7] and Kearns [8] found similar results. 


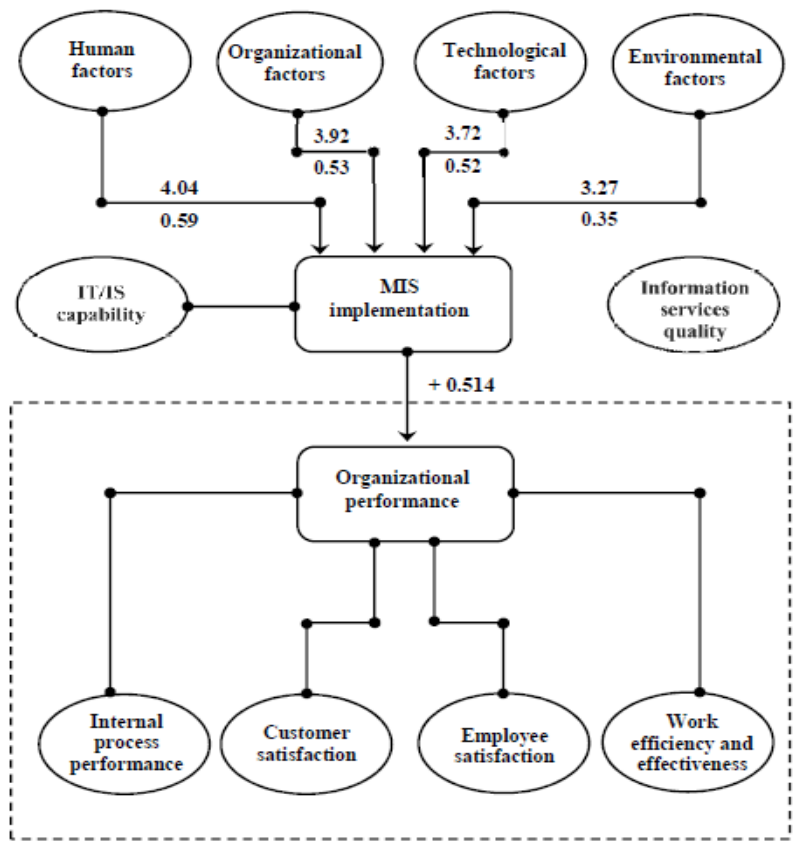

Fig. 2. Study final model

Concerning the relationship between MIS implementation and organizational performance, the findings pointed out that MIS implementation, when measured by IT/IS capability and information service quality, has a significant and positive impact on organizational performance, when measured by internal process performance, customer satisfaction, employee satisfaction, work efficiency and effectiveness. Ravichandran and Lertwomgsatien [21] found similar results. In conclusion, four factors representing twelve characteristics identified by this study play a central role in MIS implementation. Those factors have a direct effect on MIS implementation in Jordanian public institutions by enhancing the utilization of IT/IS capabilities and the quality of both information and services. MIS implementation, in turn, plays a positive role in improving organizational performance.

\section{A. Implications for Management and Research}

This study contributes to both management and research by exploring the factors affecting MIS implementation as well as the impact of MIS implementation on organizational performance. Information technology capabilities related to information storage, processing, communication and their attendant aspects are insufficient in the absence of human, organizational and technological factors, since these factors are in charge of management. The current study concluded that the investigation of the relationship between MIS implementation and organizational performance should consider the factors that might affect MIS components. Future studies can extend the proposed model using new factors and MIS constructs to understand the potential mediation role of MIS components in the relationship between MIS implementation and MIS performance. The study was conducted using a small sample selected from public institutions; the responses were restricted to managers and employees of IT/IS departments. Hence, a larger sample size and more informants might result in more generalizable results.

\section{REFERENCES}

[1] Lipaj, D., and Davidaviciene, V. "Influence of information systems on business performance," Science: Future of Lithuania, 5(10), pp. 38-45, 2013.

[2] Kharuddin, S., Ashhari, Z. and Nassir, A. "Information System and Firms' Performance: The Case of Malaysian Small Medium Enterprises," International Business Research, 3(4), pp. 28-35, 2010.

[3] Farzandipur, F., Jeddi, F. and Azimi, E. "Factors affecting successful implementation of hospital information systems," ACTA INFORM MED, 24(1), pp. 51-55, 2016.

[4] Al-Mamary, Y., Shamsuddin, A. and Aziati, N. "Factors affecting successful adoption of management information systems in organizations towards enhancing organizational performance," American Journal of Systems and Software, 2(5), pp. 121-126, 2014.

[5] Al-Mamary, Y., Shamsuddin, A. and Aziati, N. "The pilot test study of relationship between management information systems success factors and organizational performance at Sabafon Company in Yemen," International Journal of u- and e- Service, Science and Technology, 8(2), pp. 337-346, 2015.

[6] Bacha, E. "The impact of information systems on the performance of the core competence and supporting activities of a firm," Journal of Management Development, 31(8), pp. 752-763, 2012.

[7] Alshawaf, A. and Khalil, O. "IS Success factors and IS organizational Impact: Does ownership type Matter in Kuwait?," International Journal of Enterprise Information Systems, 4(2), pp. 13-33, 2008.

[8] Kearns, G. "How the internal environment impacts information systems project success: An investigation of exploitative and explorative firms," The Journal of Computer Information Systems, 48(1), pp. 63-75, 2007.

[9] Rahimi, B., Safdari, R. and Jebraeily, M. "Development of hospital information systems: User participation and factors affecting it," ACTA INFORM MED., 22(6), pp. 398-401, 2014.

[10] Fu, H-P., Chang, T-H., Ku, C-Y., Chang, T-S. and Huang, C-T "The critical success factors affecting the adoption of inter-organization systems by SMEs," Journal of Business \& Industrial Marketing, 29(5), pp. 400-416, 2014.

[11] AL-Gharaibeh, Sh. and Malkawi, N. "The impact of management information systems on the performance of governmental organizations: Study at Jordanian ministry of planning," International Journal of Business and Social Science, 4(17), pp. 101-109, 2013.

[12] DA Silveira, G. and Cagliano, R. "The relationship between interorganizational information systems and operations performance," International Journal of Operations \& Production Management, 26(3/4), pp. 232-253, 2006.

[13] Batra, S. "Impact of information technology on organizational effectiveness: A conceptual framework incorporating organizational flexibility," Global Journal of Flexible Systems Management, 7(1/2), pp. $15-25,2006$.

[14] Claver, E., Llopis, J., Gonzalez, M. and Gasco, J. "The performance of information systems through organizational culture," Information Technology \& People, 14(3), pp. 247-260, 2001.

[15] Zhu, Z. and Nakata, C. "Reexamining the link between customer orientation and business performance: The role of information systems," Journal of Marketing Theory and Practice, 15(3), pp. 187-203, 2007.

[16] Benitez-Amado, J. and Walczuch, R. "Information technology, the organizational capability of proactive corporate environmental strategy and firm performance: a resource based analysis," European Journal of Information Systems, 21, pp. 664-679, 2012.

[17] Naranjo-Gil, D. "Managerial styles and management information systems for improving organizational performance," Journal of Positive Management, 1(1), pp. 3-10, 2010.

[18] Al-Tit, A. and Hunitie, M. "The mediating effect of employee engagement between its antecedents and consequences," Journal of Management Research, 7(5), pp. 47-62, 2015.

[19] Gil-Padilla, A. and Espino-Rodríguez, T. "Strategic value and resources and capabilities of the information systems area and their impact on 
organizational performance in the hotel sector," Tourism review, 63(3), pp. 21-47, 2008.

[20] Salleh, N., Jusoh, R. and Isa, C. "Relationship between information systems sophistication and performance measurement," Industrial Management \& Data Systems, 110(7), pp. 993-1017, 2010.

[21] Ravichandran, T. and Lertwomgsatien, C. "Effect of information systems resources and capabilities on firm performance: A resourcebased perspective," Journal of Management Information Systems, 21(4), pp. 237-276, 2005.
[22] Al-Tit, A. "The effect of service and food quality on customer satisfaction and hence customer retention," Asian Social Science, 11(23), pp. 129-139, 2015.

[23] Wijaya, A. and Akbar, R. "The influence of information, organizational objectives and targets, and external pressure towards the adopting of performance measurement system in public sector," Journal of Indonesian Economy and Business, 28(1), pp. 62-83, 2013. 